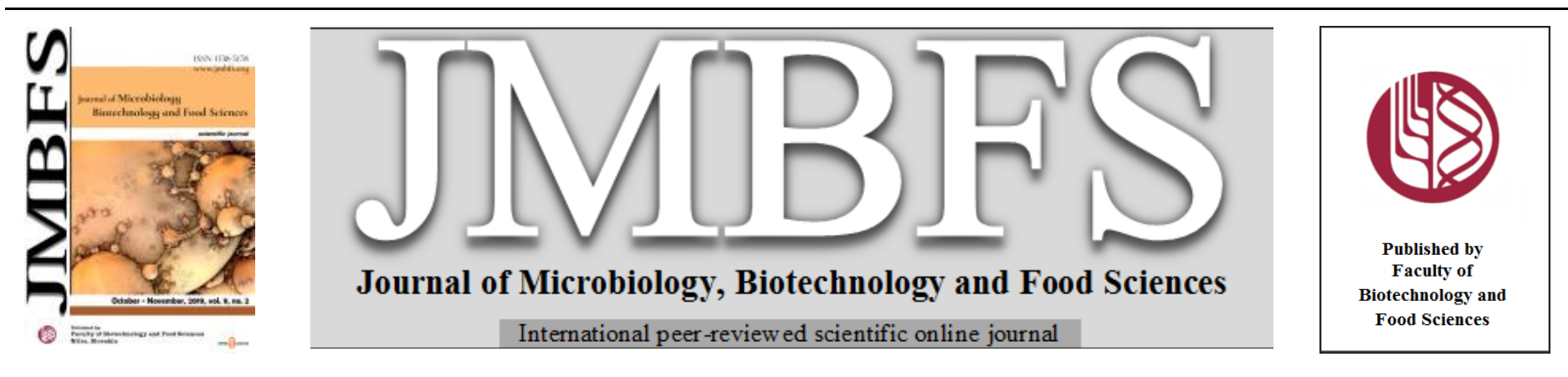

\title{
ASSESSMENT OF THE PHYTOCHEMICAL AND FUNCTIONAL PROPERTIES OF PRE-TREATED ADUWA (BALANITES AEQYPTIACA) SEED MEAL FOUR
}

\section{A.F. Ogori ${ }^{1}$, A. T. Girgih ${ }^{2}$, Lukas Hleba ${ }^{3}$, Zhanibek Yessimbekov ${ }^{4}$, Anuarbek Suychinov $^{5}$, Bibigul Abilmazhinova $^{4}$, Zukhra Abdisheva $^{4}$, Mohammad Ali Shariati ${ }^{5}$}

\author{
$\operatorname{Address}(e s):$ \\ ${ }^{1}$ Department of Home Science, Faculty of Agriculture, Federal University, Gashua, P.M.B.1005 Gashua, Yobe State, Nigeria. \\ ${ }^{2}$ Department of Food Science and Technology, Federal University of Agriculture, P.M.B. 2373, Makurdi, Benue State, Nigeria \\ ${ }^{3}$ Department of Microbiology, Faculty of Biotechnology and Food Sciences, Slovak University of Agriculture in Nitra, Nitra, Slovak Republic. \\ ${ }^{4}$ Shakarim State University of Semey, Semey, Kazakhstan. \\ ${ }^{5}$ Kazakh Research Institute of Processing and Food Industry (Semey Branch), Semey, Kazakhstan.
}

*Corresponding author: ogorifaraday@gmail.com, shariatymohammadali@gmail.com

doi: $10.15414 / j m b f s .2019 .9 .2 .354-358$

\section{ARTICLE INFO}

Received 19.6. 2019

Revised 17. 7. 2019

Accepted 23. 7. 2019

Published 1. 10. 2019

Regular article OPEN $\partial_{\text {ACCESS }}$

\begin{abstract}
Effects of pretreatments on the phytochemical properties of Balanites aeqyptiaca seed meal were investigated. Balanites aegyptiaca, belongs to the family Balaniteceae, that grows in tropical zones and is employed as animal forage. Its leaves are cooked and the seeds contains high quality oil and protein content. In this experiment, Balanites aeqyptiaca seeds were subjected to three treatments: First was toasting just before milling, oil extraction and finally meal cake production. Second was boiling, drying, toasting, milling, oil extracting and finally meal cake production. The third one was soaking overnight at ambient temperature, toasting, oil extraction and ultimately production of meal cake. In addition, raw seeds were marked as control. The main constituents were reported as 13.3-24.01\% for water, $14.4-24 \%$ for lipid, $1.43-4.02 \%$ for crude fiber, $7.36-8.97 \%$ for moisture content and $43.79-52.50 \%$ for carbohydrates. Further experiments also were performed to evaluate photo-chemicals like saponnins, alkaloids, flavonoids, phenols and tannins in pretreated samples. These compounds were ranged between $5.81-8.63 \mathrm{mg} / \mathrm{g}$ in saponnins, $0.65-1.42 \mathrm{mg} / \mathrm{g}$ in alkaloids, $9.28-11.17 \mathrm{mg} / \mathrm{g}$ in flavonoids, $2.00-4.00 \mathrm{mg} / \mathrm{g}$ in phenols and $0.00-2.40 \mathrm{mg} / \mathrm{g}$ in tannins. To characterize deeply the pre-treated samples, some of the functional properties like bulk density, least gelation capacity, oil and water absorption were also examined. The results indicated that foaming capacity ranged between $16.06-67.3 \%$, bulk density value ranged from 60-75 g/ml, Least gelation capacity was 11.03-12.74 $\mathrm{g} / \mathrm{ml}$, oil absorption and water absorption capacity values ranged between $0.00-0.01 \mathrm{~g} / \mathrm{ml}$ and $0.08-0.26 \mathrm{~g} / \mathrm{ml}$ respectively.
\end{abstract}

Keywords: Balanites aeqyptiaca, Pretreatments, phytochemical, Functional properties

\section{INTRODUCTION}

To date, the lack of food proteins has drawn increasing attention in scientific research and that is reflected in the number of studies associated with introducing new sources of protein. Kernels of B. aegyptiaca is one of the protein sources at which high oil and protein yields as well as photo-chemicals have been established (Ogori et al., 2018). Balanites leaves, which are rarely consumed in north east of Nigeria as diet have a good amount of proximate and mineral contents (ogori et al., 2017). Balanites aegyptiaca, a perennial tropical plant of the family Balanitecea, is known as desert date. Newly growing succulent shoots with the leaves, are cooked and consumed. The plant is commonly indigenous in Nigeria as Adowa (Yoruba), Adua or Aduwa (Hausa), and widely used in food preparation and traditional medications, especially in Africa and some developing countries (Wilson et al., 2009).

Balanites aegptiaca is a popular traditional medicine for treating parasite, sore throat, constipation and eye irritation (Chevallier et al., 2004). B. aegyptiaca seed powder contains a relatively high amount of protein and lipid, whereas the seed contains high level of anti-nutritional factors like tannins, oxalate and phytic acid as well (Ogori et al., 2017). Furthermore, B. aegyptiaca contains sugar, carbohydrate, protein and minerals such as potassium, calcium in significant amount (Mustapha et al., 2003). Balanites aegyptiaca seed meal products can afford to reduce malnutrition through functional supplementation and thereby contributing to food security and reduce poverty among dry land communities of Nigeria. According to the National Research Council, B. aegyptiaca products could provide raw materials for small and medium-scale enterprises in the tropical areas where it grows (NRC, 2008). The study of the nutritional composition of B. aegyptiaca seed meal in Nigeria could expand the food candidates for populations of Sahel and other dry regions of the world. Therefore, this study aims at understanding the seed meal nutritional, phytochemical and functional properties and at the same time representing a prospective of its utilization to overcome malnutrition.

\section{MATERIAL AND METHODS}

\section{Source of Raw Material and Sample preparation}

Mature B. aegyptiaca seeds were obtained from Gashua market in Yobe State of Nigeria and transported immediately to the biochemistry laboratory of the federal university Gashua. $15 \mathrm{~kg}$ of cracked seeds was weighed and its moisture value was reported at $15 \%$ for all treatments by moisture prop (E20 USA Model 121). In this experiment, 4 groups of samples were determined and allotted to roasting, soaking, and boiling treatments. The control was milled raw without treatment (As sample A or $\mathrm{RBASF}_{1}$ ). $15 \mathrm{~kg}$ of seed was roasted at $60-70^{\circ} \mathrm{C}$ for $30 \mathrm{~m}$ and then cooled (As sample B or RBASF 2 ). Another seed portion, $15 \mathrm{~kg}$ was also boiled in clean tap water at $100^{\circ} \mathrm{C}$ for 20 minutes, drained and air dried in a solar cabinet dryer at $60-70^{\circ} \mathrm{C}$ for 8 hours in order to achieve to a moisture level of 20 $\%$ and allowed to cool before roasting to mill (As sample $\mathrm{C}$ or $\mathrm{BBASF}_{3}$ ). The last seed portion was soaked over-night in clean water, drained and solar dried to about $22 \%$ moisture content before roasting and milling steps (As sample D or $\mathrm{SBASF}_{4}$.

\section{Seed processing and meal making}

The kernels were subjected to three different pretreatments of toasting only before milling, oil extraction and meal cake. The cakes from the seed milled flours were mechanically expelled by means of centrifugal screw, which is semiautomated for meal making by oil expelling as described by (Ogori et al., 2017). Figure 1 depicts the flowchart of pre-treatments. The cake was then dried using 
the solar cabinet dryer (Figure 2), well packaged and transported to the Federal University of Agriculture Makurdi, Food Chemistry and Cereal laboratories for
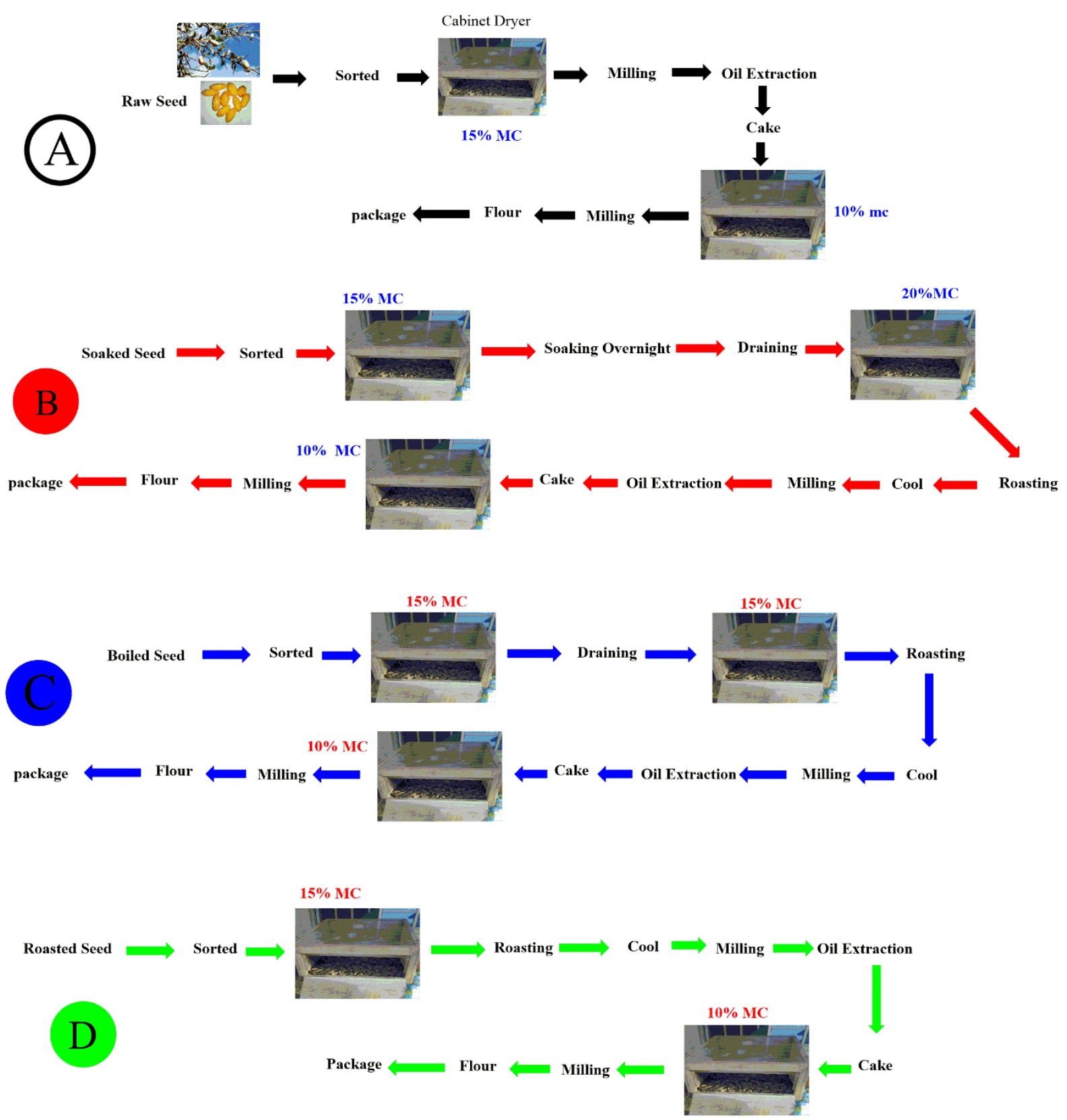

Figure 1 Flow chart showing Balanites aegytypiaca seed meal Processing, Keys: A=Raw Balanites aeqyptiaca seed flour. (control, RBASF $)_{1}$, B=Roasted Balanites aeqyptiaca seed flour $\left(\mathrm{RBASF}_{2}\right), \mathrm{C}=$ Boiled Balanites aeqyptiaca seed flour $\left(\mathrm{BBASF}_{3}\right), \mathrm{D}=\mathrm{Soaked}$ Balanites aeqyptiaca seed flour $\left(\mathrm{SBASF}_{4}\right)$

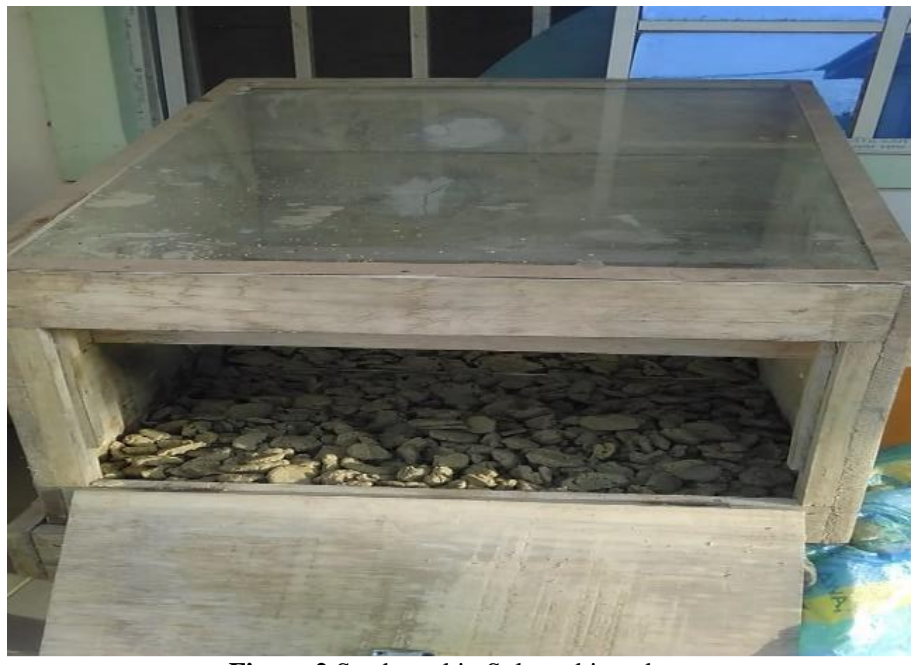

Figure 2 Seed meal in Solar cabinet dryer

\section{Proximate analysis}

\section{Moisture content determination}

The moisture content was determined by oven drying method as described by AOAC (2005). In this process, $2 \mathrm{~g}$ of the sample was dried in a hot air oven to a constant weight at $100^{\circ} \mathrm{C}$. The lost in weight was determined and reported as the moisture content and was expressed by equation 1 :

$$
\% \text { Mositure }=\frac{W_{2}-W_{1}}{W_{2}-W_{3}} \times 100
$$

Where, $\mathrm{W}_{1}$ is weight of crucible, $\mathrm{W}_{2}$ is weight of crucible + sample test portion and $\mathrm{W}_{3}$ refers to the weight of crucible + dried sample

\section{Ash content determination}

The ash content was determined by the direct heating method as described by AOAC (2005). In this method, $5 \mathrm{~g}$ of each of the samples was measured into a crucible of known weight and evaporated to dryness on steam bath. The sample was then burnt to ash in a muffle furnace at $550^{\circ} \mathrm{C}$ up to free carbon ash. It was then cooled in a desiccator and the weight of the ash was evaluated. The $\%$ ash content was calculated based on equation 2 : 


$$
\% \text { Ash }=\frac{W_{2-} W}{W_{2}-W} \times 100
$$

Where $\mathrm{W}$ is weight of crucible, $\mathrm{W}_{1}$ is weight of crucible and sample test portion and $\mathrm{W}_{2}$ refers to the weight of crucible and ash

\section{Determination of crude protein}

The crude protein of the sample was determined using the micro-Kjeddah method described by AOAC (1990). The principle of this method is based on the transformation of protein and that of the other nitrogen containing organic compounds, other than nitrites and nitrates into ammonium sulphate by acid digestion (Figure 3)
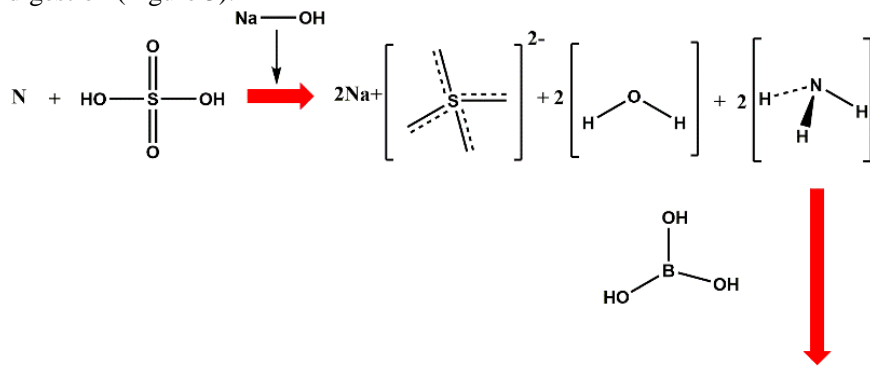

$\mathrm{NH}_{4}^{+}+\mathrm{H}_{2} \mathrm{BO}_{3}$

Figure 3 Reacting species during sample digestion

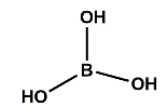

Crude protein is a measure of nitrogen in the sample. It was calculated by multiplying the total nitrogen content by a constant, 6.60 ). The crude protein was calculated by equation 3 as below:

$$
\mathrm{N}(\%)=\frac{V s-V b \times N a c i d \times 0.01401}{w} \times 100
$$

Where, Vs is titer value of $\operatorname{acid}\left(\mathrm{cm}^{3}\right), \mathrm{Vb}$ is Vol of acid titrate the blank, Nacid is concentration or normality of acid, and $\mathrm{W}(\mathrm{g})$ is original weight of sample used. $\%$ Crude protein $=\mathrm{N} \times$ conversion factor $(6.60)$

\section{Fat content determination}

The ether extraction method as described by AOAC (2005) was used to determine the fat content.

\section{Crude Fiber Determination}

The crude fiber was determined by the method described by AOAC (2005). The weight of the fiber was determined and calculated based on equation 4:

$$
\% \text { Crude Fiber }=\frac{\mathrm{W} 2-\mathrm{W} 1}{W_{3}} \times 100
$$

Where, $\mathrm{W}_{1}$ is Weight of crucible and ash, $\mathrm{W}_{2}$ is Weight of sample and crucible before ash and $\mathrm{W}_{3}$ is Weight of sample used

\section{Determination of Carbohydrate Content}

The total was determined by difference method as described by Olagunju et al (2013) and calculated based on equation 5:

$$
\mathrm{CHO}=100 \%-(\text { ash }+ \text { protein }+ \text { fat }+ \text { moisture }) \%
$$

\section{Phytochemical Analysis}

\section{Alkaloids}

The applied method was introduced by Ejikeme et al. (2014). $0.5 \mathrm{~g}$ of flour samples was diluted with $10 \mathrm{ml}$ of acid alcohol, boiled and filtered. To $5 \mathrm{ml}$ of the filtrate was added $2 \mathrm{ml}$ of dilute ammonia and $5 \mathrm{ml}$ of chloroform, and shaken gently to extract the alkaloid base. The chloroform layer was extracted with 10 $\mathrm{ml}$ of acetic acid. This was divided into two parts, fruit and the leaves. Mayer's reagent was added to one portion of the fruit extract and the leaves extract and
Draggendoff's reagent was added to other portion of extract. The formation of cream (with Mayer's reagent) or reddish brown precipitate (with Draggendoff's reagent) then quantitatively estimated.

\section{Saponins}

This method is by Ejikeme et al. (2014). To $0.5 \mathrm{~g}$ of flour samples $5 \mathrm{ml}$ of distilled water was added in a test tube. The solution was shaken vigorously and observed for a stable persistent froth. The frothing was mixed with 3 drops of olive oil and is shaken vigorously. An appearance of creamy mass of small bubbles indicated the presence of saponins. Then quantitatively estimated.

\section{Tannins}

This method is by Ejikeme et al. (2014). About $0.5 \mathrm{~g}$ of the extracts (flour) were boiled separately in $10 \mathrm{ml}$ of water in a test tube and then filtered. A few drops of $0.1 \%$ ferric chloride were added and were observed. The appearance of brownish green or a blue-black colouration indicates the presence of tannins. This was estimated quantitatively.

\section{Flavanoids}

This method is by Sofowora. (1993). Add few fragments of magnesium ribbon to the test solution and add Hydrochloric acid, pink scarlet, crimson red or occasionally green to blue color appears after few minutes. This was allowed to stabilized and quantitatiively estimated

\section{Functional Analysis}

Bulk density was determined by the method described by Chandra and Samshe. (2015). $1.0 \mathrm{~g}$ of flour sample was added to $50 \mathrm{ml}$ of distilled water at $30 \pm 2^{\mathrm{C}}$ in graduated cylinder. The suspension was mixed and shakenfor five minutes to foam. The height of foam at 30 seconds after whipping was expressed as foam capacity using equation 6 :

$$
\% \mathrm{Fc}=\frac{\mathrm{AW}-\mathrm{V}}{\mathrm{BW}} \times 100
$$

Where, $\mathrm{AW}$ is after whipping, $\mathrm{BW}$ is before whipping and $\mathrm{V}$ refers to volume.

\section{Oil absorption capacity OAC}

Bulk density was determined by the method described by Chandra and Samshe. (2015). with slight modifications.

\section{Water absorption capacity}

Bulk density was determined by the method described by Chandra and Samshe. (2015). with slight modifications. $1 \mathrm{~g}$ of flour sample was mixed with $10 \mathrm{ml}$ of distilled water and allowed to stand at ambient temperature for 30 minutes, then centrifuged for 30 minutes at $400 \mathrm{rpm}$. The supernatant was poured and the tubes weighed as W2. Water Absorption Capacity can be calculated using equation 7:

$$
\% \mathrm{WAC}=\frac{\mathrm{W} 2-\mathrm{W} 1}{W_{0}} \times 100
$$

Where, $\mathrm{W}_{0}$ is weight of empty tube, $\mathrm{W}_{1}$ is weight of tube after 30 minute of stand and $\mathrm{W}_{2}$ refers to the final weight of tube after centrifuging and decanting.

\section{Bulk Density}

Bulk density was determined by the method described by Chandra and Samshe. (2015). with slight modifications. About 100g of flour sample was measured into a cylinder, tapping the cylinder on a wooden plank up to no visible decrease in flour volume. Equation 8 was used to calculate Bulk Density.

$$
\mathrm{BD}=\frac{\mathrm{V} 2-\mathrm{V} 1}{w}
$$

Where, $V_{1}$ is Initial volume, $V_{2}$ is Final volume and $\mathrm{W}$ refers to the weight of flour.

\section{Least Gelation capacity}

Method by Chandra and Samshe. (2015). was used to determine least gelation capacity. Flour samples were made at concentration of 8-12\%w/v. The samples were then heated at $95^{\circ} \mathrm{C}$ in water for $1 \mathrm{~h}$ and cooled at room temperature for $2 \mathrm{~h}$ after overnight storage. The concentrations at which the gels did not fall out the tubes was taken as least gelation capacity. 
RESULTS AND DISCUSSION

The obtained results were analyzed by SPSS software using Duncan test $(\mathrm{p}<0.05)$.

\section{Proximate Composition of Aduwa Meal Flour}

Table 1 depicts the obtained results from proximate experiments.

Table 1 Proximate Composition of Aduwa Meal Flour

\begin{tabular}{lllllll}
\hline Sample & Protein \% & Lipid\% & Ash\% & Fiber \% & Moisture \% & $\begin{array}{l}\text { Carbohydrate } \\
\text { \% }\end{array}$ \\
\hline A & $23.92^{\mathrm{c}}$ & $15.09^{\mathrm{c}}$ & $4.14^{\mathrm{b}}$ & $3.80^{\mathrm{b}}$ & $8.97^{\mathrm{c}}$ & $43.79^{\mathrm{a}}$ \\
B & $13.35^{\mathrm{a}}$ & $25.86^{\mathrm{b}}$ & $4.47^{\mathrm{b}}$ & $3.56^{\mathrm{c}}$ & $8.97^{\mathrm{b}}$ & $43.79^{\mathrm{b}}$ \\
$\mathrm{C}$ & $20.29^{\mathrm{b}}$ & $15.58^{\mathrm{b}}$ & $2.96^{\mathrm{a}}$ & $1.43^{\mathrm{a}}$ & $8.85^{\mathrm{c}}$ & $49.89^{\mathrm{c}}$ \\
D & $24.01^{\mathrm{a}}$ & $11.40^{\mathrm{a}}$ & $0.69^{\mathrm{a}}$ & $4.02^{\mathrm{d}}$ & $7.36^{\mathrm{a}}$ & $52.50^{\mathrm{d}}$ \\
LSD & 0.27 & 0.93 & 1.60 & 0.02 & 0.11 & 0.48 \\
\hline
\end{tabular}

Means are triplicate samples. Means with same superscript along the same column are not significantly different at $\mathrm{p} \leq 0.05$.

Key: $A=$ raw balanites seed meal flour (control), $B=$ soaked balanites seed meal flour, $C=$ boiled balanites seed meal flour,

$\mathrm{D}=$ roasted balanites seed meal flour

The roasted sample showed higher protein value (24.03\%) compare to the control raw flour sample $(23.92 \%)$. This high value was followed slightly by boiled $20.29 \%$ and soaked $13.35 \%$ Aduwa seed flour sample respectively, however the boiled and soaked flour samples were significantly lower in values. These results are in agreement with Okia. (2010). on seed cake extracted by solvent method. According to Ogori et al. (2018), the protein content obtained from balanites seed cake were $17.7 \%$ in raw and $19.26 \%$ in roasted respectively. The higher value observed in roasted seed meal flour might be due to the pretreatment processing approach resulting in denaturation of protein active sites rather rupture carefully entrapped amino acid residues in the seed meal flour. The lower value found in boiled and soaked pretreated samples could be due to stages in pretreatment observed. Boiling and soaking are associated with the denaturation and leaching of macromolecules. Cooking have been reported to reduce protein digestibility of many cereals, such as rice (Kubota et al.,2017) wheat (Wu et al., 2017), sorghum (Vu, et al, 2017) and millet (Gulati et al., 2017). These authors concluded that the changes observed can be attributed to amino acid secondary structures, hydrophobicity of hydrophobic protein and protein cross-linking effects.

The lipid contents of control, soaked, roasted and boiled samples were reported as $15.09 \%, 25.86 \%, 15.98 \%$ and $11.04 \%$ respectively. One reason that boiled sample depicted the highest amount of lipid is likely releasing of fatty acids from pocket cells of seeds owing to pretreatments. Roasted samples was shown to have the least fatty acid content, selected as the best treatment to maintain lipid nutrients, whereas binding fatty acids to other macromolecules is also unavoidable. These results were in agreement with Ogori et al. (2018) on raw and roasted balanites seed cake lipid values. The ash content of soaked, boiled, roasted samples and control were $4.47 \%, 6.96 \%, 0.67 \%$ and $4.14 \%$ respectively. These result were not coincided with the report of Ogori et al. (2018). Soaking and boiling might have influenced micronutrient mineralization during this approach pretreatment.

High fiber values were observed on roasted sample $(4.02 \%)$ which was higher than the control raw sample (3.8\%). This was not coincided with the values reported by Ogori et al. (2018) for raw seed flour as (5.95) \% crude fiber and roasted $(5.20 \%)$ crude fiber respectively. The deviation was slightly followed by the soaked (3.8) \% and boiled (3.56) \% samples respectively. This indicates that roasting might have influenced Millard kind of reaction on the final flour meal. The significant differences of high moisture content observed in control $(8.97 \%)$ and soaked $(8.97 \%)$ samples might be due to water reconstitution during processing. Values from roasted sample showed that flour from this sample could stay longer on storage since water activity is a function of moisture sorption ability and triggers other side reactions. Carbohydrate value observed in roasted sample $(52.52 \%)$ was higher than the other samples, however it differed significantly with the raw sample (43.79\%), soaked (43.79\%) and boiled $(49.89 \%)$ samples.

\section{Phytochemical Properties of Aduwa Meal Flour}

Table 2 summarizes phytochemical properties such as saponin, alkaloid, flavonoid, phenol and tannin of Aduwa pretreated samples at various process treatments. Saponin contents of roasted, soaked, boiled and control were reported as $8.63 \mathrm{mg} / 100 \mathrm{~g}, 5.81 \mathrm{mg} / 100 \mathrm{~g}, 5.96 \mathrm{mg} / 100 \mathrm{~g}$, and $7.07 \mathrm{mg} / 100 \mathrm{~g}$ respectively Saponin is characterizes by coagulating, precipitating and bitterness in fluidly systems $(\mathbf{O k w u}, 2004)$. The amounts of Alkaloid in control, boiled, roasted and soaked were $1.42,1.06,1.01$ and $0.65 \mathrm{mg} / 100 \mathrm{~g}$ respectively.

Table 2 Phytochemical Properties of Aduwa Meal Flour

\begin{tabular}{|c|c|c|c|c|c|}
\hline Sample & Saponin (mg/100g) & Alkaloid (mg/100g) & $\begin{array}{l}\text { flavonoid } \\
(\mathrm{mg} / \mathbf{1 0 0 g})\end{array}$ & Phenols (mg/100g) & Tanin (mg/100g) \\
\hline $\mathrm{A}$ & $7.07^{\mathrm{a}}$ & $1.42^{\mathrm{a}}$ & $10.94^{\mathrm{c}}$ & $2.00^{\mathrm{b}}$ & $2.40^{\mathrm{a}}$ \\
\hline B & $5.81^{\mathrm{c}}$ & $0.65^{\mathrm{b}}$ & $10.52^{\mathrm{c}}$ & $2.80^{\mathrm{a}}$ & $2.00^{\mathrm{b}}$ \\
\hline $\mathrm{C}$ & $5.96^{\mathrm{b}}$ & $1.06^{\mathrm{c}}$ & $9.28^{\mathrm{a}}$ & $3.20^{\mathrm{c}}$ & $0.00^{\mathrm{a}}$ \\
\hline $\mathrm{D}$ & $8.63^{\mathrm{d}}$ & $1.01^{\mathrm{d}}$ & $11.17^{\mathrm{a}}$ & $4.00^{\mathrm{d}}$ & $0.00^{\mathrm{a}}$ \\
\hline LSD & 0.01 & $0.00^{4}$ & 1.72 & 0.00 & 0.003 \\
\hline
\end{tabular}

Means are triplicates samples. Means with same superscript along the same column are not significantly different at $\mathrm{p}<0.05$

Key: A=Raw balanites seed meal flour (control), B=Soaked balanites seed meal flour, $\mathrm{C}=\mathrm{Boiled}$ balanites seed meal flour,

$\mathrm{D}=$ Roasted balanites seed meal flour

These variations might be due to the varied processing treatments employed. Alkaloid is recognized for its anti-microbial activities (Reference is needed). The amounts of flavonoids in roasted, control, soaked and boiled samples were 11.17, $10.94,10.52$ and $9.28 \mathrm{mg} / 100 \mathrm{~g}$ respectively. Since the anti-oxidant capacity is an index of the scavenging compounds like flavonoids, it can be somewhat concluded that roasted samples would have the highest antioxidant competency. Phenols are conjugate bioactive that varies depending on expose condition in food, either in a vivo or in-vitro systems. The obtained results indicated that the type of pretreatment can affect the final content of phenol as the least and the most content were reported to be $2.8 \mathrm{mg} / 100 \mathrm{~g}$ in soaked and $4 \mathrm{mg} / 100 \mathrm{~g}$ in roasted samples.

The reported tannin contents were lower than lower than reported for balanites seed flour, papaya, apple, water melon, guava, apricot and paprika which are in the range of $(0.24-10.60 \mathrm{mg} 100 \mathrm{~g})$ (Ogori et al. ,2017; Samia, 2012). Thi further revealed that tannin migration would have taken place during the process treatment however this migration of tannin is lower in roasted sample.

\section{Functional Properties of Aduwa Meal Flour}

Table 3 depicts functional properties of pretreated Aduwa seed meal flour. Of four under experiment samples, boiled treated was reported to have the least foaming capacity as $15.09 \%$. This portrays high active amino acid residues in boiled sample that would increase foaming capacity owing to protein solubility. Bulk density is related to package and packaging. The control and soaked samples might have good packaging properties which is followed by the roasted (70\%) sample for weight and space relationship. This observation could be due to many air spaces created. Higher gelation capacity or tendency to form a gel is a reason to show good functionality in a food system. The least and the most gelation capacity were reported $11.03 \mathrm{~g} / 100 \mathrm{ml}$ in soaked and $11.4 \mathrm{~g} / 100 \mathrm{ml}$ boiled samples. Oil absorption capacity predicts emulsifying ability of macromolecule of materials, hence roasting pretreatment on Aduwa seed meal flour could favor it flour emulsifying ability. It was shown that roasted sample had the most oil absorption capacity as $0.3 \mathrm{~g} / \mathrm{ml}$. The high water absorption capacity observed in the roasted sample $(0.26 \mathrm{~g} / \mathrm{ml})$ might be due to reorientation of micro molecular bonding during roasting of the seed flour as well as during milling process. 
Table 3 Functional Properties of Aduwa Meal Flour

\begin{tabular}{|c|c|c|c|c|c|}
\hline Sample & FC(\%) & $\mathrm{BD}(\mathrm{g} / \mathrm{ml})$ & LGC(ml/g) & OAC $(\mathrm{ml} / \mathrm{g})$ & WAC $(\mathrm{ml} / \mathrm{g})$ \\
\hline A & $15.10^{\mathrm{a}}$ & $75^{\mathrm{a}}$ & $11.30^{\mathrm{a}}$ & $0.01^{\mathrm{b}}$ & $0.10^{\mathrm{a}}$ \\
\hline B & $6.73^{c}$ & $75^{\mathrm{b}}$ & $11.03^{\mathrm{b}}$ & $0.00^{\mathrm{b}}$ & $0.24^{\mathrm{d}}$ \\
\hline $\mathrm{C}$ & $15.09^{\mathrm{a}}$ & $60^{c}$ & $11.40^{\mathrm{a}}$ & $0.003^{\mathrm{a}}$ & $0.08^{\mathrm{c}}$ \\
\hline D & $16.66^{\mathrm{d}}$ & $70^{c}$ & $12.74^{\mathrm{a}}$ & $0.003^{c}$ & $0.26^{\mathrm{b}}$ \\
\hline LSD & 0.001 & 1.7 & 0.11 & 0.00 & 0.01 \\
\hline
\end{tabular}

\section{CONCLUSION}

Balanites aegyptiaca seed meal flour (Aduwa) could be produced from the raw seed at various approaches with roasting as optimal method of pretreatment. Production of Aduwa seed meal flour by soaking, boiling and roasting revealed that roasting pretreatment favors protein bioavailability, mineralization and energy content for human and ruminant metabolism. Roasted sample was reported to have higher amounts of Saponin, flavor and phenol contents. The lack of Tannin in roasted and boiled Aduwa revealed its potential utilization in food supplementation and fortification as well as in feed making. The result further indicated that foaming, gelation capacity oil, and water absorption capacities were favored by roasting pretreatment of the meal flour sample. This favorable result on roasting pretreatment was followed by soaking method for bulk density and water absorption capacity. Roasting and boiling pretreatments are the best approached methods for efficient bioactivity for Aduwa seed meal flour, hence processor should adopt it tap into this raw desert material for feed and food supplementation or fortification purposes and technology.

Conflict of Interest: There are no conflict of interest concerning this article.

\section{REFERENCES}

AOCS (1990). Official methods and recommended practices of the American Oil Chemicsts' Society (4th ed.). Champaign: American Oil Chemists' Society.

AOAC. (2000). Official Method of Analysis of the AOAC (W.Horwitz Editor) Eighteenth Edition. Washighton D.C, AOAC.

Chandra, S., Samsher, S. \& Kumari, D. (2015). Evaluation of functional property of composite flours and sensorial attributes of composites flour biscuit. Journal of Food Science and Technology, 526, 36813688. https://doi.org/10.1007/s13197-014-1427-2.

Chevallier, M.H., Vaillant, A., Bensaid, S., Sahki-Boutamine, R., Diallo, O.B., Sanou, J. Bouguedoura, N., Babin, D. (2004). Impact des pratiques humaines sur la conservation et la gestion in situ des resources forestières:cas d'Acacia tortilis raddiana et de Balanites aegyptiaca. CSFD, Rapport du projet, 57, 68.

Ejikeme, C.M., Ezeonu, C.S., \& Eboatu, A.N. (2014). Determination of physical and phytochemical constituents of some tropical timbers indigenous to Niger Delta Area of Nigeria. European Scientific Journal, 10(18), 247-270.

Gulati P. G., Li A., Holding, D. R., Santra, D., Zhang, Y., \& Rose D. J. (2017). Heating reduces proso millet protein digestibility via formation of hydrophobic aggregates. Journal of Agricultural and Food Chemistry, 65(9), 1952-1959. https://doi.org/10.1021/acs.jafc.6b05574.

Kubota M., Saito Y., Masumura, T., Watanabe, R., Fujimura, S. \& Kadowaki M (2014). In vivo digestibility of rice prolamin/protein Body-I particle is decreased by cooking. Journal of Nutritional Science \& Vitaminology, 60(4), 300-304. https://doi.org/10.3177/jnsv.60.300.

Ogori, A. F., Wakawa, L. D., Makinde, O. J. \& Vivien, O. O. (2017) Phytochemical Properties of Mechanically Expelled Pretreated Balanites Seed Oil and Cake. EC Nutrition, 8(2), 55-60.

Ogori, A.F., Makinde, O.J and Joeguluba, O. (2018). Effects of Balanites Aegyptiaca (del) Seed Cake on Haematological and Serum Biochemical Indices of Growing Rabbits. Journal of Nutritional Metabolism, 4(1), 1026 https://doi.org/10.29328/journal.afns.1001012.

Okia, C.A., Agea, J.G., Kimondo, J.M., Abohassan, A. A., Okiror, P., Obua, J. \& Teklehaimanot, Z. (2011). Use and management of Balanitesaegyptiaca in the drylands of Uganda.Nutritional value of commonly consumed desert date tree products. Research Journal of Biological Sciences, 6(1), 15-24. https://doi.org/10.3923/rjbsci.2011.15.24.

Olagunju, A., Muhammad, A., Mada, S.B., Mohammed, A., Mohammed, H.M. Mahmoud, K.T. (2012). Nutrient Composition of Tilapia zilli, Hemisynodontis membranacea, Clupea harengus and Scomber Scombrus Locally Consumed in Africa. World Journal of Life Sciences and Medical Research, 2, 16-19.

Okwu, D.E. (2004). Phytochemicals and vitamin content of indigenous species of South Eastern Nigeria. Journal of Sustain Agriculture Environment, 6, 30-34.

Samia, F.E. (2012). Chemical and nutritional evaluation of different seed flour as novel sources of protein. World Journal of Dairy and Food Sciences, 7(1),
Sofowor, A. (1993) Medicinal Plants and Traditional Medicine in Africa (2nd ed.) Spectrum Books Ltd. Ibadan, Nigeria.

Vu T. H., Bean, S., Hsieh, C. F., \& Shi, Y. C. (2017). Changes in protein and starch digestibility in sorghum flour during heat-moisture treatments. Journal of the Science of Food and Agriculture, 97(14), 4770-4779. https://doi.org/10.1002/jsfa.8346.

Wilson, O., Nadro, O., Tiyafo, M.S. \& Wurochekke G.O. (2009). Toxicity of Crude Balanites aegyptiaca Seed Oil in Rats. Journal of American Science, 5(6), 13-16.

Wu, T., Taylor, C., Nebl T., Ken, N. G., \& Bennett, L. E. (2017). Effects of chemical composition and baking on in vitro digestibility of proteins in breads made from selected gluten-containing and gluten-free flours. Food Chemistry, 233, 514-524. https://doi.org/10.1016/j.foodchem.2017.12.039. 59-65. 